\title{
Urban Informal Sector and Unemployment in Third World Cities:
}

\section{The Situation in Nigeria}

\author{
Comfort O. Chukuezi \\ Directorate of General Studies \\ Federal University of Technology \\ P. M. B 1526, Owerri, Imo State, Nigeria \\ Tel: 234-803-552-7371Ｅ-mail: fortbarn@yahoo.com
}

\begin{abstract}
The paper examines the role of urban informal sector in unemployment and poverty reduction in Nigeria. It explains that unemployment as one of the macroeconomic problems could be reduced through the informal sector participations provided it is well supported and managed through accessibility to credit and the like. Studies that have been carried out on the informal sector explain that those caught up in urban poverty resort to the informal sector as a survival strategy. It is against this background of increasing urban poverty and decline in formal employment opportunities in Nigeria that the paper tries to look into the issues of whether or not the informal sector is a panacea or a solution to unemployment in Nigeria.
\end{abstract}

Keywords: Urban, Informal sector, Unemployment, Third world, Nigeria

\section{Introduction}

There is no doubt that both the Third World and its cities have distinctive characteristics which merit specific attention. These include unemployment, poverty, etc, For the purpose of this paper the Third World will be viewed synonymously with the term peripheral capitalism as stated by Amin (1974b, 1974), Bienfeld (1975) and also as dependent capitalism as perceived by Cardoso and Faletto (1969), Don Santos (1973), in the world system. This they did as a means of designating those countries which are subordinated to or dependent upon the capitalist system, but which are not part of the central 'cores' of that system in North America, Western Europe and Japan or of the extension of these 'Cores' in Australia, New Zealand and perhaps South Africa. These exclude common Wealth of Independent States, (former USSR), China, Taiwan, North Korea, Vietnam, Laos, Cambodia and Cuba. The process of capitalist penetration of World economy and subordination of the Third World to the capitalist system is effectively described in the works of such authors as Frank $(1971,1975)$ Bairoch (1975) and Wallerstein (1974). According to Dependency theory as represented by Wallerstein (1974) that the structure of Third World societies and their cities was primarily a result of the manner in which they had been integrated into an international capitalist system from the 16th century, and the continuing pattern of integration which was responsible for a particular socio-economic formation ----- peripheral capitalism which is very different from the capitalist mode of production in the developed capitalist countries. In other words, their economies are located at the periphery of the international capitalism. Their economies are structured to meet the needs of the capitalist system (Brookfield 1975, Roberts 1978., Santos 1979, L,owder 1986). Through various mechanisms such as the control of commodity markets, the activities of the multinational companies and their subsidiaries, the control of the source of credit and interest rates, and siphoning of resources from the indigenous society, Third World countries are made to assume a dependency status. This dependency started when these countries were colonies. They were made to become the producers of raw materials and consumers of manufactured or finished products of industries in the metropolitan countries. The process was not reversed after independence. Poverty, lack of resources and small markets made the diversification of the economy difficult. Even those producing a range of commodities are not immune to market losses. Any downward turn in world market prices or poor harvest would cause a balance of payment crises. Those with larger and more monied domestic markets tended to industrialize but this process has tended to reinforce their subordinate position. Industrialization in fact fosters a new form of dependency arising from technology and raw materials. What is meant here, is that most raw materials for industries in Third World countries are not sourced locally. These industries rely primarily on imported raw materials in addition to foreign capitals. Industrial technology is introduced by multinationals that pay royalty to the holder of the patent. Payment of royalty is expensive for 
poor countries. Because of their reliance on imported technology, spare parts and raw materials, Third world industries have very poor backward linkages with other sectors of the economy; and among various branches of the industries. This in turn causes unemployment. Since the 1920s the concern of the colonial government and other employers of labour was no longer to obtain labour, but rather, how to provide work in some areas for increasing number of unemployed people (Udo 1974). In Nigeria the government as the largest employer of labour was content to continue to provide employment in the bloated civil service so long as oil revenue paid for it. The burst in oil industry resulted, in serious employment difficulties. An attempt by the government to reduce spending in accordance with revenues generated led to retrenchment of thousands of workers in the public sector and the private sector also followed suit. Unemployment assumed critical proportion in Nigeria early in the Third Republic of President Shagari. The situation has not changed since then. The present state of unemployment is serious with the Structural Adjustment Programme (SAP) and also with the March 51992 Deregulation. Because of inherent crises in the economies of Third World countries, the existing industries, since their linkages with other sectors of the economy are weak, are not able to absorb all job seekers. Further rapid urbanization with the upsurge of rural-urban migration, due to rural urban imbalance increases the problem of unemployment. Again, Most Third World cities adopt import substitution industrialization as a major component of their development strategy. Import substitution industrialization has been shown to intensify some of the problems it was designed to alleviate. These problems include balance of payment deficits, unemployment and agricultural stagnation. Since the majority of the urban population cannot be absorbed into the existing industries, they have to look for alternative ways for survival. Some take to trading, shoe shinning, artisan work, street hawking and the like. All these are informal sector activities. The informal sector has emerged as a new area of study in both the developed and developing countries. More attention has been given to the urban informal sector because of its enormous assistance in alleviating the problems of the poor and the unemployed. As the topic implies the main focus of this paper will be to locate the Third World economies within the world economic system. Further there will be a definition of the informal sector; its role in employment will also be discussed. The issue of whether or not the informal sector is a panacea or a solution to employment will be looked into; with highlights on the problems and prospects of the sector

\subsection{Research Methodology}

The methodological approach to this paper was based on reviews of multiple documents including published books and journal articles. Data were also obtained from various studies with emphasis on Nigeria from national, government and development plans that have discussed the informal sector. The third world was also reviewed in relation to evolution of the informal sector in these places.

\section{Theoretical and definitional debate}

There are many empirical studies both at the micro and macro levels on the nature, scope, extent and relative importance of some aspects of the activities in the informal sector. Also a vigorous theoretical and definitional debate has arisen on the subject. Ideas of what the sector is or should be change rapidly without agreements. Eulogies about the potentials of the 'informal' sector have been replaced by some more sanguine analysis of working conditions outside formal employment (King 1977: 217). One approach to analyzing the informal sector draws on the notion of a dualistic economy and distinguishes a simple formal/informal dichotomy akin to the modern/traditional divide (ILO 1972, Reichuuch 1978, Santos 1979; Turu and Black 1980; Zarenda 1980). Inherent conceptual and practical difficulties have given rise to alternative perspectives suggesting the mode of production engaged in (McGee 1978) or income earning opportunities (Hart 1973, Bromley and Gerry 1979) as more relevant. There is also a debate from the neo - Marxists perspective as to whether petty-commodity production is a subordinate form of the capitalist mode of production or separate mode (Moser 1978, Roberts 1978, Bromley and Gerry 1979, Masetela et al 1980, Forbes 1981a, 1981b). Analysts from various perspectives now believe that a continuum is more meaningful than dichotomies, and have increasingly sought to develop analytical continuum in terms of forms of organization, technology, scale of operation (Dick and Rimmer 1980) firm size (Dewar and Watson 1981) or income earning opportunities ranging from stable wage work to true self employment with security of income and employment as critical variables (Bromley and Gerry 1979). The ILO defines informal sector as:

A small enterprise ...... one in which the operation and administrative management lie in the hands of one or two people who are responsible for making the major decisions of the enterprise (ILO 1972.3.)

Most people use certain characteristics of the informal sector to distinguish it from the formal. For example Ekpenyong (1985) made his distinction by referring to: 
those enterprises that have relatively little capital investment, that produce in small quantities and as a result control (individually) a small share of the market, that employs less than ten people, and in which management, marketing and entrepreneurial functions are vested in the proprietor ... the organization of production units is usually along traditional lines with the proprietor at the centre of operations

In other words, there is non-separation of capital from labour. The owner of Capital is also the direct producer. There are also some characteristics common to the two sectors noted by Ekpenyong. They include production for mass market, use of tools and raw materials either originated from the modern sector or imported. Other characteristics of the informal sector include freedom of entry, both as employees and entrepreneur, unlike the formal sector where barriers to entry may sometimes be crucial. Another important characteristic of the informal sector is its non-institutionalized prize setting mechanisms which differentiates it from the formal where prices are sometimes set and maintained. Prices in the informal sector are set by bargaining between individuals involved in the transactions. Sometimes the informal sector is referred to as casual work for its lack of security of income and employment (Bromely and Gerry 1979).

\section{Discussion}

\subsection{Origin of the informal sector}

The term informal sector originated from Harts study of Ghana at a conference in Sussex in 1971 following his report on a study he undertook in Kumasi. The term was brought to prominence by the ILO/UNDP employment mission to Kenya (ILO 1972). The term had always been used in connection with the economies of the developing countries. One of the characteristics of a developing economy is its dualistic nature. The dualistic nature arises because there is an aspect of the economy where production methods, consumption patterns, business organization level and personal sophistication; the relationship with the various units of the economy etc are formal (legal in the western sense) so to say comparable with those found in developed countries. At the same time there is another aspect of the economy where the production methods and economic relationships are very informal, not recorded in official statistics, or quoted in legal terms. The first is the modern while the second is the traditional sector. These two aspects of the economy always mutually co-exist in the same community and at times so blend together that one does not know where one ends and where the other begins. The two sectors have been variously described by different authors: Geertz (1963) described the two aspects as the "firm - centred economy" and the "bazaar - type economy" respectively. Santos (1979) referred to them as "the upper"and "lower circuits" and McGee (1973) saw them as two juxtaposed systems of production, "one derived from capitalist form of production", and the other "the peasant system of production". Hart (1973) saw the two aspects of the economy as generating income opportunities, one formally and the other informally. According to Sethuraman (1976), these identification tags tend to emphasize the "distinctive organization" of production activities, whereas the usual modern/traditional dichotomy refers to the technology used. The wide range of activities engaged in are both legal and illegal, ranging from shoe shinning, street hawking, urban gardening etc. At the lowest level, some make a living from refuse scavenging. At the highest level, those who have got the requisite skill and have capital are engaged in petty-commodity production and service industries. A large percentage of workers in the informal sector are self-employed. In a study of petty comodity production in Port Harcourt and Calabar, Ekpenyong (1985) found that one third of workers were self employed, half were apprentices while less than one fifth were journeymen. Women and children form an important part of the informal sector, particularly in commerce and domestic services. The economic crises facing African countries have forced many urban women to seek employment in the informal sector so as to augment family income.

\subsection{The nature of the forms of work}

Most empirical studies of the informal sector have examined mode of labour utilization on the bases of conventional occupational categories: entrepreneurs, self-employed and associated workers, salaried workforce (skilled, semi skilled and clerical workers) and unpaid workers (family workers and apprentices). Analysis has also aimed above all at revealing the employment and training potentials of the informal sector.

The characteristics of self-employment probably vary according to the form of production. It may be relatively autonomous, or depend on other forms of production. It may be a regular activity or intermittent and so on. In other words, aggregation of various forms of self-employment denies analysts information that could help in understanding important aspects of the social dynamics. Similarly, the status of wage employment in the informal sector depends on the form of production. In small capital intensive units in certain sectors (mechanical engineering, woodwork, commerce), skill levels, forms of remuneration and regularity of work, mean that wage workers are in much the same situation as employers of large modern - sector enterprises. On the other hand, in the majority of other small enterprises which make up the heart of the informal sector, what is known as "paid 
employment", largely takes the form of semi-paid family work with many features of traditional society patterns. Although this division is a simplification, one important point becomes clear; the status of the paid workforce in the informal sector varies according to the forms of remuneration and labour utilization. That may mean that, even within the informal sector, the phase of advanced transition of certain forms of production involves the use of a paid workforce sharing common features with the workforce of large enterprises in the modern sector. At the same time, the modern sector sometimes uses an irregular workforce - temporary workers paid by the day, on piecework or seasonally - which is similar in many respects to certain forms of paid employment in the informal sector.

\subsection{The informal sector and urban poverty}

Since the early 1970s, most African counties have recognized that the reduction of urban poverty cannot be achieved without giving new dynamism to the informal sector. Paradoxically, however, little attempt has been made to integrate approaches to the informal sector into the analysis of urban poverty.

There are at least two reasons for this inadequate exploration of the relationship between urban poverty and integration into the informal sector labour market. First, observed methods have been based on the enterprise, and second, it has been explicitly or implicitly assumed that any action regarding the informal sector would necessarily help to dispel poverty. In reality, the last decade economic policy approaches to the informal sector which have been or are being adopted, have not been really appropriate for dealing with the problem of urban poverty. The informal sector may indeed be considered as a particularly effective means of eradicating poverty. However, not all the activity relating to the informal sector concerns the most deprived; and poverty is sometimes marked by a specific type of integration into the labour market of the modern sector. In other words, urban poverty overlaps the informal/modern dichotomy. Thus closer integration of the ways in which labour is employed - particularly informal work - and the phenomenon of urban poverty, is probably proof of analysis of the foundations of economic policies specially geared to reducing the occurrence of low standards of living. In this context, it is essential for the linkages between types of employment within households to be examined. Furthermore, it may be particularly valuable for drawing up the necessary action programmes to determine the relations between vulnerable employment and poverty, in terms of access to employment and career prospects.

\subsubsection{Problems and constraints facing the informal sector}

The activities in the informal sector are faced with considerable risks which may force people to change occupation in order to survive. Bad economic conditions can affect supply of inputs and sale of products, and this may ruin business for those involved. Most informal sector activities have no insurance against risks and any disaster may shatter the means of livelihood of the owner. Informal manufacturing also faces some worrying constraints. In most cities the overwhelming majority of large public and private sector companies have access to basic utilities ...... water and electricity but some of the informal manufacturers have no access to these utilities. Hostility to the informal sector is evidenced from the ILO study in zoning laws which confine small firms to peripheral urban areas well away from commercial centres of towns where market opportunities are concentrated. Periodic demolition of squatter areas, destruction of illegal structures, relocation of markets and artisan workshops, can be quite frustrating for entrepreneurs who would pay more to set up new premises. As more government now do seem to acknowledge the informal sector in statistics and development strategies, policies to promote it can still be problematic. Government intervention can mean applying regulations such as wage and price control, quality and licensing requirement. The danger here is of formalizing it and destroying those conditions which are its essence. Surveys have shown that direct State Intervention is not welcome by the majority of entrepreneurs who relish their official anonymity and independence. King (1979) for example, claims that:

\section{Most self employed groups .... share a persisting dislike of higher taxation and bureaucratization.}

The question to be answered is why the sector still persists despite all these uncertainties, insecurity and instability. If we take the Nigerian situation for example, the ill-fated government of President Muhammadu Buhari in the year 1984 tried to edge out the casual traders by destroying unlicensed trading stalls and strongly enforcing the ban on street trading and this has continued till date in many States in Nigeria. Official market sites were setup then and direct sales of products from the factory gate to consumers were encouraged. The Buhari offensive against casual traders was only partially successful. Some people did abandon their life on the margins of the city to start farming in the rural areas, but many more just went underground to become "guerilla traders", setting up their business in the not so watchful eyes of the law. Neither was the clampdown on traders popular with consumers. In fact African street sellers are seen by many as an essential fabric of the continent; in a society where transport is always difficult, the local street seller provides a valuable service, just as the road side 
mechanic, water seller and the unlicensed motor-cyclists and taxi drivers. Such services are becoming increasing important to the hard - pressed working class who often cannot afford to pay the official price for such services.

\subsubsection{Government interventions}

The demand for informal sector activities will continue to increase in accordance with the general population increase and also because of the contraction ..... temporary or otherwise of the formal sector. The Nigerian government is positively encouraging more informal sector businesses. This featured greatly in the open apprenticeship scheme of the National Directorate of Employment (NDE); and also in the establishment of skill acquisition centres all over the country. The objectives of the NDE was to promptly and effectively fight unemployment by designing and implementing innovative programmes, which are directed towards the provision of training opportunities through the guidance and management support services to graduate farmers and small scale entrepreneurs. Various governments attempted only short term solutions to solve the problem of unemployment. These include farm settlement schemes of the defunct Eastern and Western Nigerian government: The National Youth Service Corps (NYSC) Scheme of Gowon's regime and the National Directorate of Employment Programmes. The Federal government of Nigeria even stressed on the need to nurture a 'working for yourself' programme. This featured at the early stage of MAMSER (Mass Mobilization for Social and Economic Recovery). The NDE particularly coming at a time when the unemployment problem in the country had become desperate drew enthusiastic response to its programmes. In 1986 an estimated Three million people were unemployed and while school leavers and fresh university graduates poured into the labour market; retrenchment of workers was also at its highest then. The labour force sample undertaken in the third quarter of 1987 by the Federal Office of Statistics revealed that unemployment in the country was growing at the rate of $7.4 \%$ as against $5.3 \%$ as recorded in 1986. After five years operation, the NDE reported that more than 1.5 million jobs have been created nation - wide. Also the National Economic and Development Strategy (NEEDS) was introduced in March 2004 to confront various macroeconomic imbalances, social challenges and structural problems in the Nigerian economy. NEEDS as a development strategy anchored on the private sector to engineer wealth creation, employment generation and poverty reduction. As it is a medium-termed reform based development strategy and action plan for the period 2003-2007, the impact of NEEDS is yet to be felt, in combating unemployment problem and this further points to the need to seek help in the informal sector drastically to to reduce unemployment. To battle the all-time high level of unemployment in the country, any programme aimed at producing self-reliant entrepreneurs is most welcome by the government.

\subsubsection{Employment role of the Informal sector}

Employment statistics shows that the informal sector is the second largest employer of labour after agriculture in the world. Throughout the Third World, people find refuge in the informal sector. These include retrenched workers from the formal sector, unemployed youths and fresh university graduates. The informal sector is in fact a necessary feature of capitalism .... Lower wages are paid and people make up with informal sector activities. Most people even leave the formal sector for the informal. Governments rather than harass or demolish informal sector areas of operation now encourage and give them some sense of direction. Studies from different countries (Akintoye 2008) have shown that informal sector constitutes an integral part in the overall industrial sector as well as playing an active role in the growth and development of these countries. In Nigeria the informal sector accounts foe about $70 \%$ of the total industrial employment; it generates about $6.2 \%$ of the aggregate employment in United States; $22.3 \%$ in China; $80 \%$ in India and about 50\% in Isreal. Nevertheless many recent empirical studies have shown that while this sector does have positive aspects in terms of employment, incomes, and provision of goods and services for which demand exist, it is no panacea. It is not a solution to unemployment. There are many reasons for this. Surveys have shown that average enterprise size is small, working conditions hard, income unstable and sometimes marginal and growth potential low (Ghanna and Morisson 1975, Lubeck 1977; Maasdorp and Pillay 1978, Dewar and Watson 1981; Demol and Nihan 1982, Elkan et al 1983). In a survey of Port Harcourt 1985, Ekpenyong found that $84 \%$ of respondents said that their incomes were irregular, $72 \%$ felt their jobs were insecure or fairly secure and complained about short average job tenure. Nearly $48 \%$ of the respondents expressed a desire to obtain formal sector work; while the majority of those who prefer to remain in the informal sector said it was all that they were able to do in terms of their education, training and experience and that it provided a necessary supplement to the head of household's income. This suggests that most of these jobs are subsistence oriented. 


\section{Conclusion and Recommendation}

The importance of the informal sector has been increasingly realized in recent years and various aspects of the activities studied around the world; probably because it became clear that the formal (modern) sector employment was structurally incapable of absorbing all job seekers. In terms of employment which is one of the major problem areas of developing economies, the contribution of very small enterprises in the informal sector of the Third World is impressive. It is therefore necessary to continue creating awareness of the potential of the sector, especially in the role of helping to reduce the problem of unemployment. The unemployment situation would indeed be very explosive without the sector. It therefore deserves to be accorded recognition by economic and political decision makers. The informal sector as we have attempted to define it, has been a neglected sector which has received very little attention and government assistance.

Apart from its employment role, the sector fulfils numerous products and services it generates which form the major supply base for consumption especially to the poor majority of the population, at relatively cheap prices. It is also a major raw material supplier to the formal sector. The future lies in consciously strengthening the sector particularly through modernizing its management modes and techniques. More than ever, policy-makers in developing countries are recognizing the vital role of the informal sector as a mainspring of vitality and diversity in the urban economy; as a leading provider of jobs for first-time job seekers, low-skill workers and migrants from the rural areas; as a proving ground for entrepreneurial talent and as a source of skill development. On of the ways in which to start providing this sector with necessary support is by carrying out further and more comprehensive studies of the sector and by mapping out ways and means of enhancing the growth prospects of the sector within the context of the national planning effort. For example, the sector should be considered for inclusion as the recipients of credits, estates, workshops and equipment under a special government sponsored rehabilitation scheme to compensate it for the many years of total neglect in spite of its usefulness to the third world economies.

\section{References}

Akintoye I. R. (2008). Reducing unemployment through the informal sector: A case study of Nigeria. European Journal of Economics, Finance and Administrative Sciences, Issue 11.

Amin S. (ed.) (1974). Modern Migrations in West Africa. London, Oxford University Press.

Bairoach, Paul. (1975). The economic development of the Third World since 1900. London, Methuen.

Beinfield, Manfred A. (1975). The Informal sector and Peripheral Capitalism: the case of Tanzania. IDS Bulletin, 6(3), 53-73.

Bromely, J and Gerry, C (eds). (1979). Casual Work and Poverty in Third World Cities. Chichster: Wiley.

Cardoso, F.H and Enzo, F. (1969). Dependencies of Desarrollo en America Latina, Mexico DF. Siglo XXI.

Dewar, D and Watson, V. (1981). Unemployment and the Informal sector: some proposals. University of Cape Town, Urban problems research Unit.

Ekpeyong, S. (1985). Development and Operation of the Urban Informal Sector in Port Harcourt and Calabar Comparative Urban Research 10.

Frank, A.G. (1971). Capitalism and underdevelopment in Latin America, Harmondworts, Penguin.

Hart, K. (1973). Informal Income Opportunities and Urban Employment in Ghana. Journal of Modern African Studies, 11, 61-89.

Ilo. (1972). Employment, Incomes and Equality: A Strategy for increasing Productive Employment in Kenya Employment. Geneva. International Labour Organization.

King, K. (1977). The African Artisan. London Heinemann.

Lowder, S. (1986). Inside Third World Cities. London, Chrome Helm.

Lubeck, P.M. (1977). Contrasts and Continuity in dependent: Kano, Nigeria in J.C. Abu-Lughod and R Hay (eds) Third world urbanization, Chicago.

Maasdorp, G and Pillary, N. (1978). The informal sector in Clermont (Interim report 4, low cost Housing Project) University of Natal, Department of Economics.

Mc Gee, T.G. (1973). Hawkers in Hong Kong. A Study of Policy and Planning in a third World City. University of Hong Kong. Center for Asian Studies, occasional papers and monographs, 17. 
Moser, C. (1978). Informal sector of petty commodity Production: Dualism or Dependence in Urban Development. World Development, 6, 1041-66.

Roberts, B. (1978). Of Peasants. London: Edward Arnold.

Santos, N. (1979). The Shared Space. London, Methuen.

Sethuraman, S.V. (1976). The Urban Informal Sector: Concept, Measurements and Policy. International Labour Review, Vol. 114, No. 1, July to August, P 70.

Turu, M.L and Black, P.A. (1980). The Urban Informal Sector and market Imperfections. South African Journal of Economics, 48(1), 12-27.

Wallerstein, I,M. (1974). The Modern World System: Capitalist Agriculture and the origins of the European World Economy in the $16^{\text {th }}$ Century. New York, Academic Press.

Zarenda, H. (1989). Imperfections in the Urban Informal Sector Model. South African Journal of Economics, 48(3), 297-305. 